\title{
PERAN ROHIS DALAM PEMBENTUKAN SIKAP KEAGAMAAN PESERTA DIDIK
}

\section{(Studi Atas Peran Kerohanian Islam Nurul Ilmi SMAN 3 Kota Pekalongan)}

\author{
A.M. Wibowo \\ Balai Penelitian dan Pengembangan Agama Semarang \\ Email: attara.wibowo@gmail.com
}

\section{ABSTRAK}

Penelitian ini mencoba melihat kiprah rohis dalam usaha membentuk sikap keagamaan peserta didik di tengah maraknya isu-isu radikalisme yang ditimbulkan dari program kegiatan rohis. Tujuan dari penelitian ini ada 3 yaitu (1) untuk memperoleh deskripsi profil Organisasi Kerohanian Islam, (2) mengetahui secara mendalam tentang peran Kerohanian Islam dalam membentuk watak dan sikap peserta didik SMA, (3) Diperoleh deskripsi terkait faktor-faktor yang mempengaruhi sikap keagamaan peserta didik SMA, dan (4) Mengetahui jaringan komunikasi antara Rohis dengan organisasi Islam dan alumninya. Adapun subyek penelitian ini adalah pada Rohis takmir masjid Nurul Ilmi SMAN 3 Pekalongan. Dengan menggunakan metode penelitian kualitatif penelitian ini menghasilkan 4 temuan. Pertama, profil organisasi rohis takmir masjid Nurul ilmi memiliki peran dalam upaya dakwah Islam yang dikemas dalam kegiatan-kegiatannya seperti kuliah pagi, pengajian, istighosah dan lain sebagainya. Kedua, organisasi kerohanian Islam memiliki andil atau peran yang besar dalam menyemaikan dan membentuk sikap keagamaan peserta didik SMA melalui kegiatan-kegiatan yang diselenggarakannya. Ketiga, faktor internal pendukung kegiatan rohis/takmir dalam perannya membentuk sikap keagamaan adalah visi misi takmir, kepemimpinan, kooordinasi dan konsulidasi antara pengurus takmir atau rohis. Secara eksternal faktor pendukung eksternal berupa kebijakan kepala sekolah, adapun faktor penghambat internal yang menjadi penghambat rohis/takmir adalah tidak adanya mekanisme yang mengatur organisasi, dan pembagian tugas dan fungsi pada masing-masing struktur takmir/rohis, secara eksternal penghambat kegiatan Rohis adalah kebijakan kepala sekolah yang tidak mewajibkan kegiatan rohis menjadi kegiatan wajib di sekolah, sarana dan prasarana yang kurang menunjang kegiatan takmir/rohis, serta masalah pendanaan 
dalam menjalankan organisasi. Keempat, takmir masjid Nurul Ilmi menjalin kerjasama dengan perguruan tinggi Islam, dan ulama-ulama di Kota Pekalongan.

Kata kunci: Rohis, sikap keagamaan, faktor pendukung, penghambat, jaringan

\section{PENDAHULUAN}

Banyak usaha yang dilakukan oleh pemerintah melalui lembaga pendidikan untuk pengembangan potensi peserta didik agar menjadi manusia yang beriman dan bertakwa kepada Tuhan YME dan berakhlak mulia, yaitu melalui pendidikan agama dan keagamaan di sekolah. Sekolah merupakan salah satu media pendidikan formal memiliki peran penting dalam membina dan membentuk watak, sikap dan perilaku, baik melalui proses pembelajaran intrakurikuler, kokurikuler maupun kegiatan ekstra kurikuler.

Secara makro, Pendidikan Agama Islam bertujuan untuk menciptakan suasana religius dalam kehidupan pribadi, sekolah, dan masyarakat. Secara teoritik, Muhaimin (2012: 306-307) mengungkapkan model-model penciptaan suasana religius di sekolah. Pertama dengan model struktural, yakni penciptaan suasana religius yang disemangati oleh adanya peraturan-peraturan, pembangunan kesan, baik dari dunia luar atas kepemimpinan atau kebijakan suatu lembaga pendidikan atau suatu organisasi. Model ini biasanya bersifat "top down", yakni kegiatan keagamaan yang dibuat atas prakarsa atau instruksi dari pejabat/pimpinan atasan. Kedua, model formal, yaitu penciptaan suasana religius yang didasari atas pemahaman bahwa pendidikan agama adalah upaya membina untuk mengajarkan masalah-masalah kehidupan akhirat saja atau kehidupan rohani saja, sehingga pendidikan agama dihadapkan dengan pendidikan non keagamaan, pendidikan ke Islaman dengan non keIslaman dan seterusnya. Ketiga, model mekanik yaitu penciptaan suasana religius yang didasari oleh pemahaman bahwa kehidupan terdiri atas berbagai aspek, dan pendidikan di pandang sebagai penanaman dan pengembangan seperangkat nilai kehidupan yang masing-masing bergerak dan berjalan menurut fungsinya. Keempat model organik, yaitu penciptaan suasana religius yang disemangati oleh adanya pandangan bahwa pendidikan agama adalah kesatuan sebuah sistem yang terdiri atas komponen-komponen yang rumit yang berusaha mengembangkan pandangan/ semangat hidup organisasi, yang dimanifestasikan dalam sikap hidup dan keterampilan hidup yang religius.

Rohis merupakan bagian dari organisasi intra sekolah sebagai salah satu media untuk pembinaan moral dan akhlak, berwawasan islami dan pribadi yang tangguh menghadapi masa depan. Visi Rohis yaitu menghidupkan dakwah Islam yang 
kondusif, sedangkan misi Rohis adalah memberikan pendidikan dan pelatihan tentang ke-Islaman dan organisasi serta optimalisasi program kerja dakwah. Rohis menjadi penting karena beberapa peran ideal di dalamnya, yang menjadi bagian integral dari upaya pendidikan sekolah. Rohis tidak menjadi sarana eksklusifikasi dalam beragama, tetapi harus menjadi tempat persemaian semangat ke-Islaman dan ke-Indonesiaan, bukan untuk ideologisasi Islam (Tolkhah, 2012). Hal inilah yang diharapkan mengapa Rohis perlu eksis dan dikembangkan di sekolah-sekolah.

Penelitian ini merupakan penelitian kualitatif yang bertujuan untuk mengetahui peran Rohis dalam pembentukan sikap keagamaan peserta didik. Secara operasional, tujuan penelitian ini ada 4 yaitu sebagai berikut.

1. Diperoleh deskripsi tentang profil Organisasi Kerohanian Islam yang ada di SMA, baik dilihat dari bentuk organisasi maupun kegiatan keagamaan.

2. Mengetahui secara mendalam tentang peran Kerohanian Islam dalam membentuk watak dan sikap peserta didik SMA.

3. Diperoleh deskripsi terkait faktor-faktor yang mempengaruhi sikap keagamaan peserta didik SMA.

4. Mengetahui jaringan komunikasi antara Rohis dengan organisasi Islam dan alumninya.

Penelitian ini mengambil subyek rohis Takmir Masjid Nurul Ilmi SMAN 3 Pekalongan. Hasil penelitian ini diharapkan dapat digunakan sebagai bahan masukan untuk menyusun kebijakan oleh pemerintah, cq Kementrian Agama RI maupun Kementrian Pendidikan dan Kebudayaan terkait dengan bagaimana memformulasikan kegiatan keagamaan di SMA. Bagi SMA yang diteliti, hasil penelitian ini diharapkan dapat digunakan sebagai bahan masukan dalam meningkatkan pembinaan terkait dengan peran Kerohanian Islam di SMA.

\section{METODE PENELITIAN}

Penelitian ini dilakukan dalam waktu 6 bulan, yaitu bulan Juni sampai dengan Desember 2014. Metode yang digunakan dalam penelitian ini adalah penelitian kualitatif dengan sasaran penelitian tentang peran Kerohanian Islam (Rohis) dalam pembentukan sikap keagamaan peserta didik SMA adalah Sekolah Menengah Atas Negeri (SMAN) yang berada pada perkotaan di Provinsi Jawa Tengah dengan subyek penelitian Rohis takmir Masjid Nurul Ilmi SMAN 3 Pekalongan. Dengan asumsi bahwa remaja di perkotaan lebih terkontaminasi dari dampak negatif globalisasi informasi dan globalisasi budaya, dibandingkan dengan remaja yang tinggal di daerah 
pedesaan. Teknik pengumpulan data dalam penelitian ini menggunakan empat macam teknik, yaitu wawancara, observasi, dokumen, dan kuesioner. Uji keabsahan data dalam penelitian ini menggunakan trianggulasi data. Sedangkan analisis data kualitatif dilakukan dengan jalan bekerja dengan data, mengorganisasikan data, memilah-milah menjadi satuan yang dapat dikelola, mensintesiskan, mencari dan menemukan pola, menemukan apa yang penting dan apa yang dipelajari dan memutuskan apa yang dapat di informasikan kepada orang lain (Bogdan: 1982). Analisis dalam penelitian kualitatif dilakukan pada saat pengumpulan data berlangsung dan setelah pengumpulan data dalam periode tertentu. Pada saat wawancara, peneliti sudah melakukan analisis terhadap jawaban yang diwawancarai. Aktivitas dalam analisis data model Miles and Huberman secara sistematis meliputi data reduction, data display dan conclusion drawing/verification mengikuti alur sebagaimana berikut.

Bagan 1

Model Interaktif

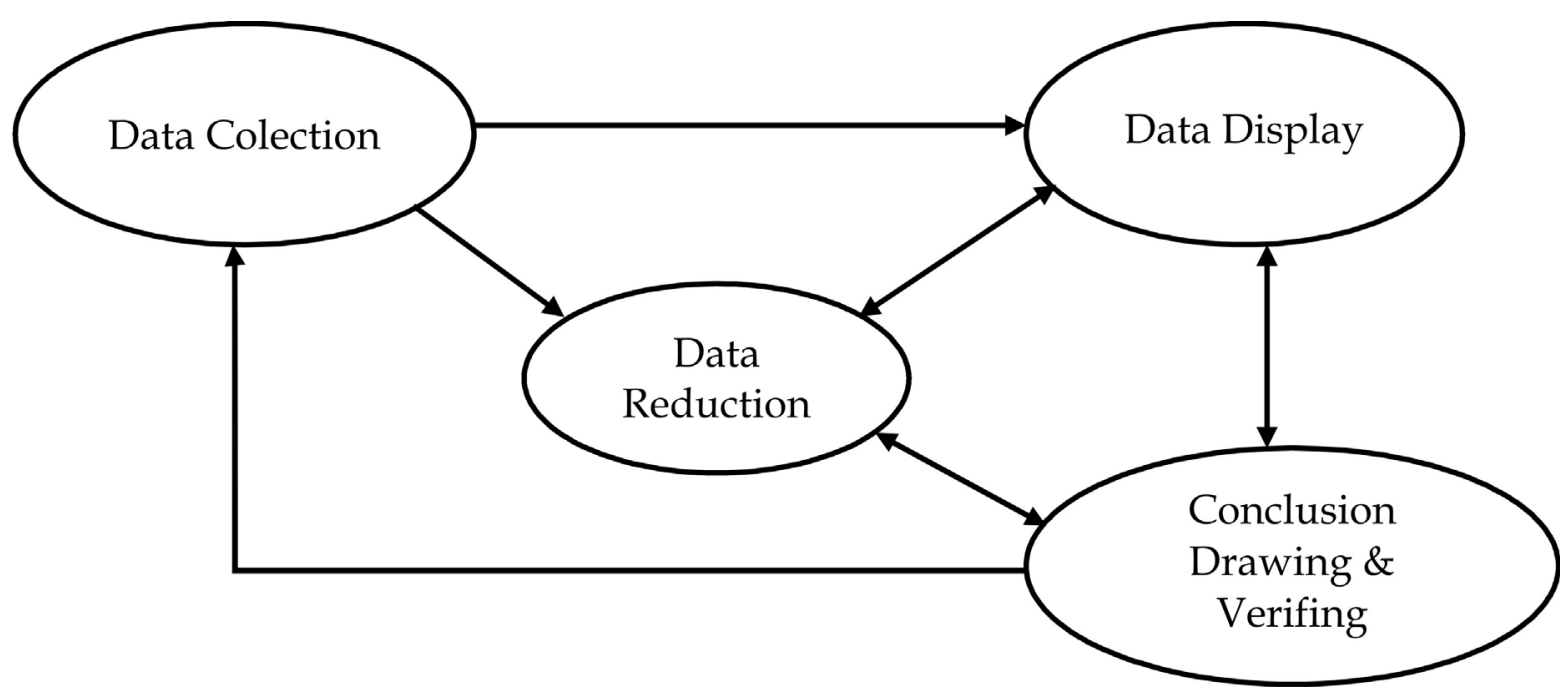

\section{TEMUAN PENELITIAN}

\section{Kultur Pekalongan Sebagai Kota Bersumbu Pendek}

Masyarakat Kota Pekalongan merupakan masyarakat yang berkarakter kuat. Karena kuatnya karakter tersebut maka tak heran kota Pekalongan termasuk daerah sumbu pendek yang mudah tersulut akibat konflik etnis pribumi dan non pribumi, juga antar agama. Tercatat beberapa kasus konflik yang pernah terjadi di kota ini. Konflik yang menonjol diantaranya adalah konflik antara penduduk asli dengan kolonialisme Jepang. Dalam konflik ini Pekalonganlah daerah pertama kali dari seluruh wilayah di Indonesia yang terbebas dari kekuasaan Jepang yaitu pada 7 
Oktober 1945 sebagaimana di tulis dalam buku Revolusi Tiga Daerah (revolusi dalam revolusi) karya Anton E Lucas Pustaka Utama Grafiti pada tahun 1989. (Lucas:1989).

Peristiwa lainnya adalah konflik antar etnis di kota Pekalongan yang berujung pada pengusiran dan perusakan warga Tiong Hoa oleh warga Pekalongan. Peristiwa itu bermula dari penyobekan Mushaf al Quran pada hari Rabu tanggal 22 November 1995 oleh Yoe Sin Yung seoarang warga etnis Tiong Hoa, seorang pedagang kelontong di Jalan Hayam Wuruk, Kampung Pekauman, Pekalongan. Tindakan penyobekan mushaf al Quran itu dilihat oleh beberapa orang. Dua hari setelah peristiwa itu, pada siang hari seusai shalat Jumat, terjadi aksi protes masyarakat terhadap sikap pelecehan tersebut. Mula-mula masyarakat ingin melihat pelaku tetapi kemudian setelah massa berkumpul berubah menjadi aksi pengrusakan dan kerusuhan. Kerusuhan merambat ke seluruh kota Pekalongan. Ratusan jama'ah masjid Jami' bergerak dan turun ke jalan-jalan. Satu toko milik warga Jalan Hayam Wuruk, tempat tinggal keluarga pelaku penyobekan mushaf al-Quran berhasil dijebol. Massa terus bergerak meluas di sekitar jalan Hayam Wuruk hingga ke luar kota Pekalongan. Aparat keamanan yang sudah siap dari awal dan memblokade jalan Hayam Wuruk tidak berhasil menahan laju barisan pengunjuk rasa. Para pengunjuk rasa melempari toko-toko sambil meneriakan takbir. Kerusuhan berlangsung hampir 4 jam. Jadi kurang dari 75 toko milik pedagang non pribumi di sepanjang jalan Hayam Wuruk sampai jalan Sultan Agung hancur berantakan. Dua mobil rusak dan sejumlah sepeda motor yang diparkir di sepanjang jalan juga hancur. Di luar kota Pekalongan, pabrik tekstil Lokatek di Pekalongan Barat dirusak dan sebuah bus milik perusahaan dibakar. Sejumlah toko dan rumah terpaksa ditutup dan pintu depannya ditempeli tulisan "orang pribumi asli, ya Allah" (Suromo, dalam Gatra vol IXX: 43).

Dari hasil penelitian yang dilakukan oleh Miftahul Aliyah (2008) Di kota Pekalongan terungkap bahwa masalah yang berhubungan dengan agama sifatnya sangat sensitif, mudah tersulut apabila terjadi penyimpangan. Pekalongan merupakan daerah yang mayoritas masyarakatnya beragama Islam dan mereka dikenal sebagai masyarakat yang kuat pengamalan ajaran agamanya. Oleh karena itu, masalah-masalah sosial yang menyentuh emosi keagamaan warga cepat mendapat respon dari masyarakat.

Dari latar belakang itulah maka penelitian ini ingin menggali lebih dalam mengenai peran-peran lembaga keagamaan di sekolah umum yang tergabung dalam organisasi Kerohanian Islam (Rohis) dalam pembentukan karakter keagamaan peserta didik khususnya pembentukan sikap keagamaan peserta didik dilihat dari 
sikap kepada Tuhannya, orang tua, guru, lingkungan, sesamanya, dan sikap organisasinya

\section{Profil Takmir Masjid Nurul IImi SMAN 3 Pekalongan}

Organisasi Kerohanian Islam (Rohis) SMAN 3 Pekalongan bernama Takmir masjid Nurul Ilmi. Keberadaan organissasi Takmir masjid Nurul Ilmi berada di bawah sub organisasi OSIS (seksi ketakwaan kepada Tuhan Yang Maha Esa). Rohis di SMAN 3 telah ada sejak tahun $2000 .{ }^{1}$ Fungsi takmir masjid Nurul Ilmi adalah merupakan kepanjangan tangan dari seksi ketakwaan sub organisasi OSIS dalam melaksanakan kegiatan-kegiatan yang bersifat keagamaan seperti pada saat momen-momen peringatan hari besar Islam (PHBI). Idealnya segala kegiatan yang bersifat keagamaan Islam diserahkan kepada Takmir.

\section{Visi, Misi dan Pembina Takmir}

Visi Takmir masjid Nurul Ilmi adalah mencetak generasi penerus yang mampu melanjutkan syiar Islam melalui kegiatan keagamaan. Misi yang dikembangkan ada empat. Pertama, yaitu membentuk generasi penerus yang dapat mengamalkan agama Islam. Kedua, mewujudkan generasi penerus menjadi pemimpin yang berakhlak mulia. Ketiga, mengembangkan sikap dan kepribadian sesuai ajaran Islam. Keempat, mempersiapkan generasi penerus yang mampu menghadapi tantangan zaman.

Pembina Rohis di SMAN 3 terdiri dari 2 orang yaitu satu orang guru PAI dinas pendidikan dan satu lagi guru PAI dari Kementerian Agama. Keduanya saling membantu dalam membina dan mengarahkan takmir masjid Nurul Ilmi SMAN 3. Diantara 2 guru pembina takmir masjid ini satu orang guru telah mengajar di SMAN 3 Pekalongan lebih dari 10 tahun yaitu Malikus Sholekha dari dinas pendidikan, sedangkan guru PAI lainnya baru mengajar di sekolah ini kurang dari 3 tahun yaitu Kasmali dari Kementerian Agama.

\section{Stuktur Organisasi dan Tugas Takmir Masjid Nurul IImi}

Pada periode 2013/2014 secara organisatoris struktur organisasi Takmir Masjid Nurul Ilmi terdiri dari Pembina utama yang meliputi Kepala sekolah dan wakil kepala bidang Kesiswaan. Di bawah pembina Utama adalah OSIS Sekbid iman dan ketakwaan, dan pembina takmir. Di bawah pembina takmir terdiri dari ketua dan wakil ketua takmir, sekretaris (dua orang), bendahara (2 orang), koordinator seksi ibadah (2 orang) yang membawahi seksi Zuhur (6 orang), seksi salat jumat (4 orang)

${ }^{1}$ Wawancara dengan Malikus Sholekha guru PAI dan Pembina Rohis SMAN 3 tanggal 27 Agustus, 2 September 2014. 
dan seksi keputrian (6 orang), koordinator seksi dakwah (1 orang) yang membawahi seksi kuliah pagi (6 orang) dan seksi dakwah (6 orang), koordinator seksi kesenian (1 orang) yang membawahi seksi kesenian (7 orang), serta koordinator seksi humas (1 orang) yang membawahi seksi Humas (6 orang).

Perekrutan kader atau anggota inti dilakukan setiap awal tahun ajaran baru. Pembukaan dan pendaftaran perekrutan anggota baru pada awal tahun ajaran baru dibuka selama dua hari bersamaan dengan organisasi-organisasi ekstrakurikuler di bawah sub organisasi OSIS. Setelah proses pendaftaran selesai maka tidak seluruh siswa yang mendaftar diterima. Siswa harus melalui beberapa seleksi berupa tes tertulis dan wawancara. Tes tertulis adalah untuk mengetahui sejauh mana pengetahuan agama calon kader. Sedangkan wawancara untuk mengetahui kefasihan membaca Alquran dan motivasi para calon kader.

Mekanisme pergantian pengurus inti dari tahun ke tahun relatif memiliki polapola yang sama. ${ }^{2}$ Pertama, sudah menjadi keputusan bersama bahwa ketua Takmir harus di pegang oleh siswa kelas XI dan yang menjadi pengurus harian Takmir. Hal ini dikarenakan proses pengkaderan dari kelas $X$ sudah matang. Kedua, pengurus lama yang telah naik ke kelas XII mengajukan calon ketua dan wakil ketua dari pengurus yang sudah naik ke kelas XI. Begitu juga bagi pengurus di kelas X yang telah naik ke kelas XI. Pengajuan calon-calon ketua dan wakil ketua takmir biasanya mengkerucut pada 5 orang calon. Ketiga, setelah mengerucut pada 5 calon tahapan seleksi berikutnya adalah uji kompetensi. Uji kompetensi ini meliputi ke fasihan mengaji, jumlah hafalan surat dalam al Quran, jumlah hafalan doa, dan orasi atau kultum. Keempat, adalah seleksi dari pembina rohis. Seleksi ini dilakukan oleh pembina rohis terkait motivasi, dan visi dan misi bagi calon ketua takmir. Seleksi inilah yang merupakan kunci terpilihnya ketua, wakil ketua, sekretaris, hingga bendahara.

\section{Program Kerja Takmir Masjid Nurul IImi}

Program kerja pada seksi ibadah. Seksi ibadah bertanggung jawab untuk melaksanakan program-program yang meliputi salat Zuhur berjamaah, salat Jumat dan keputrian pada hari Jumat, kuliah pagi setiap hari minggu, Khotmil Quran pada akhir bulan, dan pembacaan asmaul husna pada setiap pertemuan. Semua kegiatan kecuali keputrian di selenggarakan di Masjid Nurul Ilmi. Seksi ibadah ini bertugas

\footnotetext{
${ }^{2}$ Berdasarkan wawancara dengan Malikus sholekh, M Rasyid ridho, Laili Khumairus Syifa (ketua dan wakil Ketau Takmir masjdi nurul Ilmi) Awal September 2014.
} 
untuk mempersiapkan segala sesuatu demi kelancaran program seperti kebersihan masjid, mempersiapkan mukena, hingga menyiapkan absensi.

Seksi Humas bertangjawab untuk melaksanakan program-program yang terkait dengan pengelolaan website, pembuatan buku induk, dan piket masjid. Sejauh penelusuran peneliti website Takmir Masjid Nurul Ilmi tidak ada, yang ada adalah facebook takmir masjid Nurul ilmi. Dalam facebook ini terdapat beberapa menu pilihan berupa kronologi, tentang, foto, dan suka. Menu catatan di berisi tentang tema-tema kajian Islam.

Seksi kesenian bertugas melaksanakan program-program yang terkait dengan program KRETA (Kreasi Anak Takmir) yang dilaksanakan setiap sebulan sekali. Mereka mengkoordinir latihan rebana, marawis, tartil-tilawah, tari saman yang dilaksanakan setiap hari Selasa dan Jumat.

Seksi dakwah bertugas untuk melaksanakan kegiatan-kegiatan takmir seperti BRILIAN (belajar Islam di Akhir Bulan) yang dilaksanakan satu bulan sekali, Cermin hati yang dilaksanakan 2 bulan sekali, serta penerbitan bulletin Nurul Ilmi yang terbit 1 bulan sekali.

\section{Jumlah anggota Takmir Masjid Nurul IImi}

Di SMAN 3 Pekalongan seluruh peserta didik yang beragama Islam adalah anggota Takmir Masjid Nurul Ilmi. Hal ini merupakan kebijakan dari guru PAI yang disetujui oleh kepala sekolah. Seluruh program kegiatan Takmir berpengaruh pada nilai akhir mata pelajaran PAI. Karena merupakan kegiatan yang mengikat maka dibuatlah aturan-aturan yang mengikat peserta didik. Aturan tersebut terkait tingkat kehadiran peserta didik pada setiap kegiatan takmir.

Kegiatan takmir yang diperhitungkan tingkat kehadirannya adalah salat Zuhur berjamaah, salat jumat berjamaah, keputrian, dan kuliah Ahad pagi. Pemantau kehadiran siswa pada kegiatan tersebut adalah seksi ibadah dan dakwah.

"Setiap angkatan ada perwakilannya takmir yang bertugas absensi siswa, kalau temannya sendiri yang mengabsen tidak susah karena mereka yang tahu temantemannya sendiri,"ujar Malikus ${ }^{3}$

\section{Kegiatan Takmir Masjid Nurul IImi}

1. Kegiatan harian

Program kegiatan takmir masjid/rohis yang dilaksanakan setiap hari adalah kegiatan salat Zuhur berjamaah di masjid sekolah. Pada SMAN 3 Pekalongan,

${ }^{3}$ Wawancara dengan Malikus Solekha 
kegiatan salat Zuhur ini terkontrol dan terjadwal. Masing-masing angkatan kelas memiliki jadwal yang telah ditentukan. Pada kegiatan salat Zuhur berjamaah ini dikoordinir oleh seksi ibadah Takmir yang setiap angkatan ada perwakilannya.

Tugas seksi ibadah takmir masjid adalah melakukan himbauan berupa mengingatkan, melakukan absensi, mempersiapkan masjid yang meliputi kebersihan masjid, mempersiapkan mukena, adzan dan iqomat serta kembali merapikan kembali masjid menjadi bersih dan rapi. Petugas absen bertugas mencatat teman-temannya baik yang hadir maupun yang berhalangan hadir. Absensi ini setiap minggu dilakukan perekapan dan dilaporkan kepada guru PAI sebagai pembina takmir. Khotib Salat Jumat telah ditentukan jadwalnya selama satu tahun berdasarkan pasaran jawa. ${ }^{4}$ Para khotib merupakan guru-guru PAI di sekolah lain ataupun ulama di sekitar SMAN 3. Petugas absen bertugas mencatat teman-temannya baik yang hadir maupun yang berhalangan hadir. Absensi ini setiap minggu dilakukan perekapan dan dilaporkan kepada ketua takmir dan kepada guru PAI sebagai pembina takmir.

Tingkat kehadiran peserta didik ikut berpengaruh pada penilaian mata pelajaran PAI. Bagi peserta didik yang tingkat kehadirannya tidak memenuhi maka akan diberikan hukuman sebagai pengganti pahala. Pengganti pahala tersebut berupa menyumbang mukena untuk inventaris masjid, atau menyumbang buku-buku bacaan ke Islaman yang disumbangkan pada perpustakaan PAI sekolah.

\section{Kegiatan Mingguan Takmir}

Program kegiatan mingguan yang dilaksanakan pada takmir masjid Nurul Ilmi SMAN 3 Pekalongan adalah rapat rutin Takmir masjid Nurul Ilmi, Salat Jumat di masjid, keputrian, marawis, dan kuliah Ahad pagi. Takmir masjid Nurul Ilmi memiliki hari khusus untuk rapat dan koordinasi pengurus pada hari Selasa. Pada kegiatan rapat rutin tersebut dibahas tentang rekap kegiatan harian dan mingguan termasuk absensi kegiatan, serta membahas tentang rencana kegiatan-kegiatan yang sifatnya besar seperti peringatan hari besar Islam, dan Ajang Kreasi Seni Islami (AKSI), serta kegiatan-kegiatan lain yang bersifat eksidental seperti ziarah atau infak. Namun tidak jarang pada hari Selasa juga digunakan untuk latihan kesenian marawis.

Kegiatan mingguan lainnya adalah Salat Jumat di masjid Nurul Ilmi. Sama halnya dengan kegiatan salat Zuhur, kegiatan salat Jumat yang dikoordinir seksi ibadah Takmir masjid Nurul Ilmi terkontrol dan terjadwal. Masing-masing angkatan kelas

\footnotetext{
${ }^{4}$ Pasaran jawa adalah nama-nama hari pada penaggalan jawa yaitu pon, wage, kliwon, legi dan pahing.
} 
memiliki jadwal yang telah ditentukan gilirannya. Pada kegiatan salat Jumat berjamaah ini dikoordinir oleh seksi ibadah Takmir yang setiap angkatan ada perwakilannya.

Bagi siswi siswi putri sebagai pengganti Jumatan dilakukan kegiatan keputrian. Kegiatan keputrian yang dilaksanakan biasanya membahas tentang hal-hal yang bersifat kewanitaan yaitu masalah menstruasi, kebersihan badan, bercukur dan lain sebagainya.

Kegiatan mingguan lainnya adalah kuliah Ahad pagi yang dilaksanakan setiap minggu di masjid Nurul Ilmi SMAN 3 Pekalongan. Kegiatan inipun terkontrol dan terjadwal. Masing-masing angkatan kelas telah dijadwalkan untuk mengikuti kuliah Ahad pagi. Kegiatan kuliah pagi atau takmir masjid Nurul Ilmi menyingkatnya dengan istilah Kulpag dikoordinir oleh seksi dakwah. Seksi dakwah melakukan persiapan berupa absensi, kebersihan masjid, dan pengumuman kepada angkatan kelas yang mendapat jadwal mengikuti kulpag. Untuk para penceramah telah dihubungkan oleh pembina Takmir. Metode yang digunakan dalam kuliah pagi adalah metode ceramah arah di mana penceramah duduk di atas kursi dan meja dan peserta didik duduk di lantai. Jamaah laki-laki dan perempuan duduk terpisah. Tidak ada kegiatan tanya jawab dalam kuliah pagi minggu itu. Namun menurut pembina takmir biasanya terdapat kegiatan tanya jawab untuk menjembatani keingintahuan siswa.

Meskipun tidak ada paksaan bagi peserta didik untuk mengikuti kuliah pagi, namun kesadaran untuk mengikuti kuliah pagi sudah ditanamkan sejak di kelas X. Kebiasaan yang ditanamkan sejak masih di kelas $X$ itulah yang diharapkan dapat berlanjut hingga kelas XII. Pihak takmir dan pembina takmir tetap melakukan pemantauan terhadap tingkat kehadiran siswa pada setiap kegiatan kuliah pagi. Peserta didik yang intensitas kehadirannya rendah atau tidak masuk sama sekali akan diberikan hukuman berupa pengganti pahala. Pengganti pahala tersebut dapat berupa mukena, sarung, atau buku bacaan ke Islaman yang akan disumbangkan di masjid Nurul Ilmi dan perpustakaan PAI sekolah.

"Pemberian sanksi bukan bermaksud memberatkan tetapi juga belajar bersyukur dan menambah pahala dengan menyumbang rukuh, sarung dan perpustakaan," tutur Malikus seusai Kuliah Pagi. ${ }^{5}$

Kegiatan mingguan lainnya adalah di bidang kesenian. Kegiatan kesenian yang diprogramkan Takmir Masjid Nurul Ilmi adalah latihan rebana, Marawis, tartil

\footnotetext{
${ }^{5}$ Wawancara dengan Malikus Sholekha, Pembina Takmir, Minggu, 31 Agustus 2014 di Masjid Nurul Ilmi SMAN 3 Pekalongan.
} 
tilawah, dan tari saman. Kegiatan ini dilaksanakan setiap seminggu 2 kali yaitu setiap hari Selasa dan Jumat setelah rapat rutin takmir selesai.

3. Kegiatan Bulanan Takmir masjid/Rohis

Program kegiatan bulanan yang dilaksanakan pada Takmir Masjid Nurul Ilmi SMAN 3 Pekalongan meliputi Khotmil Quran, Kreasi Anak takmir (KRETA), Belajar Islam Akhir Bulan (Brilian), Buletin Nurul Ilmi, dan Cermin hati. Khusus untuk kegiatan cermin hati dilaksanakan setiap 2 bulan sekali.

Kegiatan khotmil Quran merupakan kegiatan membaca al Quran sebanyak 30 Juz yang dibaca secara bersama-sama. Kegiatan ini dilaksanakan setiap akhir bulan. Tujuan dilaksanakannya khotmil Quran ini adalah membiasakan peserta didik untuk membaca Alquran, dan menambah wawasan tentang Alquran .

Kegiatan kreasi anak takmir adalah kegiatan yang dilakukan terkait untuk menyalurkan aspirasi dan bakat. Kreasi Anak Takmir ini dilakukan dalam bentuk majalah dinding yang dipasang di serambi masjid Nurul ilmi. Isi majalah dinding ini berupa motivasi, sindiran, ajakan kepada kebaikan, cerita bergambar dan lain sebagainya.

Kegiatan belajar Islam akhir bulan atau Brilian adalah program kegiatan takmir untuk memperdalam ilmu ke Islaman yang dilakukan pada minggu keempat setiap bulannya. Belajar Islam merupakan kegiatan mentoring yang langsung diampu oleh pembina takmir masjid Nurul Ilmi yang sekaligus guru PAI SMAN 3 Pekalongan.

Tema-tema yang diajarkan melalui kegiatan mentoring adalah tema-tema yang berhubungan dengan topik-topik kekinian. Contoh tema yang pernah diajarkan pada kegiatan mentoring adalah masalah jihad dan masalah mengucapkan selamat hari raya kepada umat non muslim. Pada tema jihad kegiatan mentoring mengajarkan bahwa jihad yang benar adalah tidak harus malalui jalan perang. Sebab jihad artinya adalah bersungguh-sungguh. Belajar bersungguh sungguh bagi anak sekolah juga merupakan bagian dari jihad. Mengucapkan hari raya kepada umat non muslim menurut para mentor adalah haram hukumnya. Mengucapkan selamat hari raya kepada umat non muslim termasuk salah satu yang merusak akidah, sebab merupakan bentuk pengakuan akan kebenaran agama lain.

Kegiatan bulanan takmir masjid lainnya adalah menerbitkan Bulletin Nurul Ilmi. Bulletin ini dikoordinir oleh sie dakwah. Bulletin ini berisi tentang meteri-materi khutbah dan materi keagamaan yang lain yang terbit setiap akhir bulan.

Kegiatan bulanan Takmir Masjid Nurul Ilmi selanjutnya adalah cermin hati. Cermin Hati adalah sebuah bentuk evaluasi dari kegiatan-kegiatan yang telah 
dilakukan oleh takmir masjid Nurul Ilmi. Dalam kegiatan Cermin Hati ini dibahas mengenai kendala-kendala selama melakukan kegiatan, mulai dari masalah kepanitiaan siapa bekerja siapa atau yang tidak bekerja, kesan-kesan atas kegiatan yang telah dilakukan, evaluasi atas pekerjaan, sampai dengan curahan hati para pengurus takmir. Kegiatan cermin hati ini dilakukan setiap dua bulan sekali.

4. Kegiatan tahunan dan eksidental Takmir masjid

Kegiatan tahunan yang dilaksanakan oleh Takmir masjid Nurul Ilmi adalah meliputi kegiatan Peringatan Hari Besar Islam (PHBI). Peringatan PHBI ini meliputi doa bersama pada tanggal 1 dan 10 Muharram, Maulid nabi Muhammad saw pada bulan Rabiul Awwal. Bahkti sosial yang dilakukan pada bulan Muharram, doa Nifsyu Syaban pada bulan Syaban, kemah bakti ramadhan dan Pesantren ramadhan, Halal Bi halal pada bulan Syawal, serta kegiatan Idul Adha berupa salat ied dan penyembelihan hewan Qurban pada bulan Dzulhijjah.

Ada satu program kegiatan takmir masjid Nurul Ilmi berskala besar, yaitu Ajang Kreasi Seni Islami se Kota dan kabupaten Pekalongan. Event ini berisi tentang perlombaan perlombaan dan seni Islam untuk tingkat SD hingga SMAN yang meliputi seni marawis, rebana, story telling dan lain sebagainya. Karena skalanya yang besar, maka kegiatan ini dilaksanakan dua tahun sekali. Adapun dana untuk penyelenggaraan kegiatan ini diambil dari dana infak, donatur serta mengusahakan sponsor dari luar sekolah.

Kegiatan eksidental yang dilaksanakan oleh Tamir masjid Nurul Ilmi adalah kegiatan pada yang dilaksanakan pada saat ada peristiwa-peristiwa penting atau kebutuhan penting pengurus takmir. Salah satu kegiatan eksidental yang pernah dilaksanakan oleh Takmir Masjid Nurul Ilmi adalah pengumpulan infak yang akan disumbangkan pada korban yang menimpa umat muslim Gaza pada perang Palestina dan Israel tahun 2014. Kegiatan eksidental lainnya adalah tadzabur alam. Kegiatan ini dilakukan oleh pengurus takmir apabila mengalami kejenuhan dan ingin melakukan refreshing untuk penyegaran fisik dan psikis. Menurut beberapa informan biasanya kegiatan tadzabur alam ini di lakukan menjelang akhir tahun kepengurusan takmir.

\section{Sikap Keagamaan Peserta Didik Sebagai Akibat Kegiatan Takmir}

Penelitian ini juga mencoba mengukur sikap keagamaan peserta didik sebagai akibat dari kegiatan takmir masjid/Rohis yang mengikat seluruh peserta didik SMAN 3 Pekalongan. Peserta didik yang dijadikan sampel untuk mengukur sikap keagamaan peserta didik diambil sebanyak 48 peserta didik. Ke 48 sampel tersebut 
diambil dari pengurus takmir / rohis dan peserta didik secara umum pada kelas XI dan XII.

Adapun sikap keagamaan yang diukur meliputi 6 hal, yaitu sikap kepada Tuhan, sikap kepada guru, sikap kepada sesama, sikap kepada alam sekitar, dan sikap organisasi. Interpretasi hasil pengisian kuesioner menggunakan rata-rata skor penilaian sebagai acuan penentuan kategori dengan penjelasan sebagai berikut.

$$
\begin{array}{ll}
\text { Rata-rata skor maksimal } & =5 \\
\text { Rata-rata skor minimal } & =1 \\
\text { Jumlah kategori } & =5 \\
\text { Interval kelas } & =\frac{5-1}{5}=0,8
\end{array}
$$

Tabel 1 Interpretasi rata-rata skor hasil pengisian instrumen sikap keagamaan peserta didik.

\begin{tabular}{|c|c|}
\hline Rata-rata Penilaian & Interpretasi \\
\hline$>4,2$ s.d. 5 & Sangat baik \\
\hline$>3,4$ s.d. 4,2 & Baik \\
\hline$>2,6$ s.d.3,4 & Cukup baik \\
\hline$>1,8$ s.d, 2,6 & Kurang baik \\
\hline$>1$ s.d. 1,8 & Tidak baik \\
\hline
\end{tabular}

\section{Sikap Peserta Didik kepada Tuhan}

Instrumen untuk mengetahui sikap peserta didik kepada tuhannya sebagai akibat dari aktifitas rohis yang dilakukan dalam kegiatannya di sekolah terdiri dari 7 buah pertanyaan yang mencakup rukun iman. Hasil interpretasi sikap kepada Tuhan tertera pada tabel 2.

Sikap keagamaan peserta didik terkait sikap terhadap Tuhan berdasarkan kuesioner diperoleh nilai rata-rata 4,78. Hal ini jika dikaitkan dengan interpretasi rata-rata skor hasil pengisian Instrumen sikap keagamaan peserta didik termasuk dalam kategori sangat baik. Sikap peserta didik terhadap Tuhannya dengan interpretasi sangat baik tersebut tidak bisa dipisahkan dari kegiatan-kegiatan keagamaan yang diselenggarakan oleh sekolah. Meski belum dibuktikan berapa persen pengaruhnya, namun dari hasil pengumpulan data menunjukkan bahwa kegiatan-kegiatan keagamaan yang diselenggarakan oleh sekolah dan dikoordinir oleh Takmir masjid/rohis berisi tentang tema-tema sikap manusia kepada Tuhan. 
Tabel 2 Rata-Rata Sikap peserta didik Kepada Tuhannya

\begin{tabular}{|l|c|c|}
\hline \multicolumn{1}{|c|}{ Item pernyataan } & Nilai Rata-rata & Interpretasi \\
\hline $\begin{array}{l}\text { Keberadaan bumi, langit dan seisinya adalah bukti adanya } \\
\text { Allah Swt }\end{array}$ & 5 & Sangat baik \\
\hline Saya masih ragu akan terjadinya hari akhir/kiamat & 4,8 & Sangat baik \\
\hline $\begin{array}{l}\text { Sebagai seorang muslim saya harus mempercayai adanya } \\
\text { qadha dan qadhar Allah }\end{array}$ & 4,7 & Sangat baik \\
\hline $\begin{array}{l}\text { Perbuatan baik dan perbuatan buruk yang kita lakukan akan } \\
\text { selalu dicatat oleh malaikat }\end{array}$ & 4,8 & Sangat baik \\
\hline $\begin{array}{l}\text { Semua amal perbuatan manusia akan mendapat balasan dar } \\
\text { Allah Swt kelak di akhirat }\end{array}$ & 4,9 & Sangat baik \\
\hline $\begin{array}{l}\text { Saya percaya bahawa Muhammad adalah ndbi dan rosul } \\
\text { terakhir }\end{array}$ & 4,9 & Sangat baik \\
\hline $\begin{array}{l}\text { Takdir adalah ketetapan Allah oleh karena itu sebagai } \\
\text { hambanya saya tidak perlu melakukan usaha }\end{array}$ & 4,4 & Sangat baik \\
\hline Rata-rata & 4,78 & Sangat baik \\
\hline
\end{tabular}

\section{Sikap Perserta Didik kepada Orang Tua}

Instrumen untuk mengetahui sikap peserta didik kepada orang tua sebagai akibat dari aktivitas kegiatan takmir masjid/rohis yang dilakukan di sekolah terdiri dari 7 buah yang meliputi kepatuhan, kesopanan, kewajiban anak, kewajiban orang tua, dan masalah kebersihan. Hasil interpretasi sikap kepada orang tua tertera pada tabel 3.

Tabel 3 Rata-Rata Sikap peserta didik kepada orang tua

\begin{tabular}{|l|c|c|}
\hline \multicolumn{1}{|c|}{ Item Pernyataan } & Nilai Rata-rata & Interpretasi \\
\hline $\begin{array}{l}\text { Menyayangi dan patuh pada perintah orang tua adalah } \\
\text { kewajiban anak }\end{array}$ & 4,8 & Sangat baik \\
\hline $\begin{array}{l}\text { Kita harus bersikap sopan santun terhadap orang tua kita } \\
\text { baik dalam tingkah laku maupun dalam tutur kata }\end{array}$ & 4.8 & Sangat baik \\
\hline $\begin{array}{l}\text { Jika orang tua saya sedang sakit saya tidak harus } \\
\text { merawatnya }\end{array}$ & 4.5 & Sangat baik \\
\hline $\begin{array}{l}\text { Mendoakan orang tua yang sudah meninggal dunia adalah } \\
\text { kewajiban saya sebagai anak yangsaleh }\end{array}$ & 4.8 & Sangat baik \\
\hline Kebersihan di rumah adalah tanggung jawab orang tua saja & 4.2 & Sangat baik \\
\hline $\begin{array}{l}\text { Jika melihat teman menghardik orang tuanya maka saya } \\
\text { akan menasihati teman saya itu }\end{array}$ & 4.4 & Sangat baik \\
\hline $\begin{array}{l}\text { Orang tua yang baik adalah orang tua yang memanjakan } \\
\text { anaknya }\end{array}$ & 3.7 & Baik \\
\hline Rata-rata & 4,45 & Sangat baik \\
\hline
\end{tabular}

Sikap keagamaan peserta didik terkait sikap terhadap orang tua berdasarkan kuesioner diperoleh nilai rata-rata 4,45. Hal ini jika dikaitkan dengan interpretasi rata-rata skor hasil pengisian Instrumen sikap keagamaan peserta didik termasuk dalam kategori sangat baik. Materi-materi yang diangkat dalam setiap kegiatan 
keagamaan yang dikelola oleh takmir masjid/ rohis menunjukan sikap keagamaan terhadap orang tua menjadi bahan utama dalam kegiatan dakwah. Materi-materi tersebut sikap terhadap orang tua tersebut terkadang menjadi tema utama, namun tak jarang diselipkan pada materi-materi yang lain.

Dari kuesioner sikap kepada orang tua ada satu item pertanyaan yang memiliki interpretasi baik, yaitu pernyataan tentang orang tua yang baik adalah orang tua yang memanjakan anaknya. Dari 48 siswa, 13 diantaranya menjawab dengan pilihan netral, 2 orang menjawab setuju, dan 2 siswa tidak memberikan jawaban.hal ini artinya 28, 2 persen siswa sangat setuju jika orang tua yang baik adalah yang memanjakan anaknya. Hal ini tampaknya harus menjadi perhatian oleh pihak sekolah terutama pembina Takmir/rohis. Ada baiknya dalam mengelola tema tentang sikap dan sikap-sikap terhadap orang tua porsinya ditambah atau disisipkan pada materi-materi lain. Dengan demikian muncul harapan sikap siswa terhadap orang tua akan semakin baik.

\section{Sikap Peserta Didik kepada Guru}

Instrumen untuk mengetahui sikap peserta didik kepada guru sebagai akibat dari aktifitas kegiatan takmir masjid/rohis yang dilakukan di sekolah teridiri dari 7 buah pertanyaan. Tujuh buah pertanyaan tersebut meliputi kepatuhan, keteladanan, dan rasa simpati. Hasil interpretasi sikap kepada guru adalah sebagai berikut.

Tabel 4 rata-rata sikap peserta didik kepada guru

\begin{tabular}{|l|c|c|}
\hline \multicolumn{1}{|c|}{ Item Pernyataan } & Nilai Rata-rata & Interpretasi \\
\hline $\begin{array}{l}\text { Guru adalah sosok mulia yang harus dihormati dan } \\
\text { diteladani }\end{array}$ & 4,5 & Sangat baik \\
\hline $\begin{array}{l}\text { Banyaknya tugas dari guru sekolah membuat saya tidak } \\
\text { sempat melaksanakan salat }\end{array}$ & 4,3 & Sangat baik \\
\hline $\begin{array}{l}\text { Saya tidak suka kepada guru yang memberikan hikuman } \\
\text { fisik kepada siswa }\end{array}$ & 4,2 & Sangat baik \\
\hline $\begin{array}{l}\text { Sebagai seorang siswa saya harus mentaati ajaran guru } \\
\text { meskipun ada yang tidak sesuai dengan ajaran agama }\end{array}$ & 4,2 & Sangat baik \\
\hline $\begin{array}{l}\text { Jika guru yang tidak saya senangi sakit saya tidak akan } \\
\text { membezuknya }\end{array}$ & 4,2 & Sangat baik \\
\hline Saya akan melupakan guru saya jika sudah lulus dari SMA & 4,1 & Sangat baik \\
\hline $\begin{array}{l}\text { Jika ada seorang guru muslim yang jarang berjamaah salat } \\
\text { dzuhur di masjid sekolah saya akan menirunya }\end{array}$ & 4,3 & Sangat baik \\
\hline Rata-rata & 4,25 & Sangat baik \\
\hline
\end{tabular}

Sikap keagamaan peserta didik terkait sikap terhadap guru berdasarkan kuesioner diperoleh nilai rata-rata 4,25. Hal ini jika dikaitkan dengan interpretasi rata-rata skor hasil pengisian instrumen sikap keagamaan peserta didik termasuk dalam kategori sangat baik. Dari kuesioner tersebut terlihat bahwasannya peserta didik 
selalu mengambil sisi-sisi positif guru dan tidak mau mencontoh sisi negative guru. Hal tersebut terlihat dari sikap peserta didik yang melihat guru sebagai sosok yang patut diteladani. Karena keteladanan itulah maka peserta didik tidak mau mentaati guru yang tidak sesuai dengan ajaran agama, tidak meniru tindakan guru muslim yang jarang berjamaah salat dzuhur di masjid sekolah.

\section{Sikap dan Sikap Kepada Sesama}

Instrumen untuk mengetahui sikap peserta didik kepada sesama sebagai akibat dari aktifitas kegiatan takmir masjid/rohis yang dilakukan di sekolah terdiri dari 10 buah pertanyaan. Sepuluh buah pertanyaan tersebut meliputi toleransi, kekerasan atas nama jihad, persahabatan, dan tindakan menyimpang seperti alkohol, narkoba dan aborsi. Hasil interpretasi sikap kepada sesama teman adalah sebagai berikut.

Tabel 5 rata-rata sikap peserta didik kepada sesama

\begin{tabular}{|l|c|c|}
\hline \multicolumn{1}{|c|}{ Item pernyataan } & Nilai rata-rata & Interpretasi \\
\hline Saya menjaga jarak dengan teman yang berlainan agama & 3,9 & Baik \\
\hline $\begin{array}{l}\text { Saya setuju denganaksi kekerasan yang mengatasnamakan } \\
\text { jihad }\end{array}$ & 4,3 & Sangat baik \\
\hline $\begin{array}{l}\text { Menurut saya, menolong orang lain tidak perlu memandang } \\
\text { perbedaan agama }\end{array}$ & 4,6 & Sangat baik \\
\hline $\begin{array}{l}\text { Saya tidak akan membalas perbuatan jahat yang dilakukan } \\
\text { teman kepada saya }\end{array}$ & 4,1 & Sangat baik \\
\hline $\begin{array}{l}\text { Saya tidak terlalu peduli dengan teman maupun orang lain } \\
\text { yang sedang dilanda bencana }\end{array}$ & 4,4 & Sangat baik \\
\hline Saya menghormati perayaan hari raya agama lain & 3,7 & Baik \\
\hline $\begin{array}{l}\text { Saya ingin sekali menerima ajakan teman untuk mencoba } \\
\text { rasanya narkoba sehingga tahu mengapa dilarang }\end{array}$ & 4,9 & Sangat baik \\
\hline $\begin{array}{l}\text { Saya memiliki geng yang akan membela saya ketika saya di } \\
\text { jahili orang atau kelompok lain }\end{array}$ & 3,7 & Sangat baik \\
\hline $\begin{array}{l}\text { Saya setuju dengan tindakan teman yang terpaksa } \\
\text { melakukan aborsi agar dapat melanjutkan sekolah demi } \\
\text { masa depannya }\end{array}$ & 4,4 & Sangat baik \\
\hline $\begin{array}{l}\text { Perbedaan agama, suku, dan budaya tidak menghalangi } \\
\text { saya untuk menjalin persahabatan }\end{array}$ & 4,5 & Sangat baik \\
\hline Rata-rata &
\end{tabular}

Sikap keagamaan peserta didik terkait sikap terhadap sesama berdasarkan kuesioner diperoleh nilai rata-rata 4,25. Hal ini jika dikaitkan dengan interpretasi rata-rata skor hasil pengisian instrumen sikap keagamaan peserta didik terhadap sesama termasuk dalam kategori sangat baik. Dari 10 item pernyataan pada kuesioner sikap terhadap sesama terdapat dua item yang memperoleh interpretasi baik. Dua item tersebut adalah terkait dengan penghormatan terhadap perayaan hari raya agama lain dan manfaat bergabung dengan kelompok-kelompok yang disebut geng. Meskipun dua item pertanyaan ini memperoleh nilai rata-rata 3,7 namun perlu 
kiranya perhatian khusus pada para Pembina Rohis agar tema dimasalah ini diberikan perhatian lebih sehingga sikap peserta didik terhadap hari raya agama lain dan masalah gang menjadi lebih baik.

Terkait dengan penghormatan terhadap perayaan hari raya agama lain, pembina takmir mengajarkan bahwa mengucapkan selamat hari raya kepada agama lain dapat merusak akidah. Hal ini menurut pembina takmir adalah bentuk pengakuan akan kebenaran agama orang lain. Sebagai bentuk toleransi pembina takmir menyarankan agar mempersilakan agama lain merayakan hari raya keagamaannya dengan cara tidak mengganggunya baik dengan ucapan selamat atau perbuatan lainnya. Hal ini dapat mempererat persatuan tanpa harus merusak akidah peserta didik. Dari beberapa kegiatan mentoring maupun pengajian yang diselenggarakan oleh Takmir masjid/Rohis berisi tentang ajaran hal-hal yang dapat merusak akidah umat Islam salah satunya adalah mengucapkan selamat hari raya kepada umat agama lain. ${ }^{6}$

\section{Sikap Peserta Didik kepada Alam Sekitar}

Instrumen untuk mengetahui sikap peserta didik kepada alam sekitar sebagai akibat dari aktifitas kegiatan takmir masjid/rohis yang dilakukan di sekolah teridiri dari 7 buah pertanyaan. Tujuh buah pertanyaan tersebut meliputi beberapa pernyataan kewajiban menjaga lingkungan. Hasil interpretasi sikap kepada Tuhan adalah sebagai berikut.

Tabel 6 rata-rata sikap peserta didik kepada alam sekitar

\begin{tabular}{|l|c|c|}
\hline \multicolumn{1}{|c|}{ Item pernyataan } & Nilai rata-rata & Interpretasi \\
\hline Menjaga kelestarian alam adalah kewajiban setiap manusia & 4,8 & Sangat baik \\
\hline $\begin{array}{l}\text { Saya akan memperingatkan orangyang membuang sampah } \\
\text { sembarangan }\end{array}$ & 4 & Sangat baik \\
\hline $\begin{array}{l}\text { Penebangan pohon secara liar di hutan adalah perbuatan } \\
\text { yang wajar dan manusiawi }\end{array}$ & 4,5 & Sangat baik \\
\hline $\begin{array}{l}\text { Saya mendukung adanya gerakan penghijauan di daerah } \\
\text { pantai, hutan, dan tanah gundul }\end{array}$ & 4,7 & Sangat baik \\
\hline $\begin{array}{l}\text { Knalpot motor milik saya, saya ubah agar berbunyi nyaring } \\
\text { sehingga terlihat keren dan menjadi pusat perhatian }\end{array}$ & 4,5 & Sangat baik \\
\hline $\begin{array}{l}\text { Mencari ikan dengan cara setrum atau apotas sangat } \\
\text { menguntungkan }\end{array}$ & 4,6 & Sangat Baik \\
\hline $\begin{array}{l}\text { Mencorat-coret tembok dengan pilox atau spidol adalah } \\
\text { ingin menunjukan jati diri saya dan geng saya }\end{array}$ & 4,7 & Sangat baik \\
\hline Rata-rata & 4,46 & Sangat baik \\
\hline
\end{tabular}

${ }^{6}$ Wawancara dengan M rasyid Ridho dan Khumaerotussyifa pada saat bersamaan di serambi masjid Nurul Ilmi SMAN 3 Pekalongan. 
Sikap keagamaan peserta didik terkait sikap terhadap alam sekitar berdasarkan kuesioner diperoleh nilai rata-rata 4,46. Hal ini jika dikaitkan dengan interpretasi rata-rata skor hasil pengisian instrumen sikap keagamaan peserta didik terhadap sesama termasuk dalam kategori sangat baik. Melihat hasil yang sangat baik ini maka tema-tema yang terkait sikap peserta didik terhadap lingkungannya perlu dipertahankan. Artinya adalah kiranya tema-tema yang diusung dalam kegiatan takmir mengambil tema tentang sikap kepada alam sekitar yang meliputi kelestarian, penjagaan terhadap dan alam lingkungan.

\section{Sikap Peserta Didik kepada Organisasi}

Instrumen untuk mengetahui sikap peserta didik kepada organisasi takmir/ rohis teridiri dari 7 buah pertanyaan. Tujuh buah pertanyaan tersebut meliputi keterlibatan aktif dalam organisasi, hubungan antara alumni, dan kegiatan mentoring tentang jihad. Interpretasi sikap kepada organisasi adalah sebagai berikut.

Table 7 rata-rata Sikap peserta didik kepada organisasi.

\begin{tabular}{|l|c|c|}
\hline \multicolumn{1}{|c|}{ Item pernyataan } & Nilai rata-rata & Interpretasi \\
\hline Saya terlibat aktif dalam organisasi Rohis Sekolah & 3,6 & baik \\
\hline $\begin{array}{l}\text { Saya selalu mengikuti kegiatan yang diadakan Rohis } \\
\text { meskipun bukan pengurus }\end{array}$ & 3,6 & Baik \\
\hline $\begin{array}{l}\text { Kegiatan Rohis menambah pengetahuan agama dan } \\
\text { keagamaan saya }\end{array}$ & 3,2 & Sangat baik \\
\hline $\begin{array}{l}\text { Saya tertarik adanya pemutaran filmfilm bertema jihad di } \\
\text { sekolah }\end{array}$ & 3,9 & baik \\
\hline $\begin{array}{l}\text { Rohis di sekolah saya masih menjalin hubungan baik } \\
\text { dengan para alumni Rohis pada perioct sebelumnya }\end{array}$ & 3,1 & baik \\
\hline $\begin{array}{l}\text { Kegiatan mentoring yang saya ikuti banyak diisi oleh para } \\
\text { alumni }\end{array}$ & 3,5 & baik \\
\hline $\begin{array}{l}\text { Kegiatan mentoring yang saya ikuti banyak mengkaji } \\
\text { masalah jihad di jalan Allah }\end{array}$ & 3,7 & baik \\
\hline Rata-rata &
\end{tabular}

Sikap keagamaan peserta didik terkait sikap terhadap organisasi berdasarkan kuesioner diperoleh nilai rata-rata 3,7. Hal ini jika dikaitkan dengan interpretasi ratarata skor hasil pengisian instrumen sikap keagamaan peserta didik terhadap sesama termasuk dalam kategori baik. Dari 48 jumlah peserta didik yang dijadikan sampel penelitian hanya sekitar 34 yang yang menjadi pengurus Takmir dan Rohis. Oleh karena itu, sangat wajar jika secara organisasi sikap keagamaan peserta didik baik. Namun, menurut hemat peneliti kondisi seperti ini justru menunjukkan bahwa kegiatan-kegiatan yang di programkan dan dilaksanakan telah membawa pengaruh baik terhadap sikap kegamaan peserta didik. 
Dari uraian temuan tentang sikap keagamaan peserta didik sebagai akibat dari pelaksanaan kegiatan takmir/rohis sebagaimana di atas dapat ditarik satu benang merah bahwa terbukti takmir masjid/rohis ikut berperan dalam memperdalam pengetahuan, pemahaman, dan perubahan sikap keagamaan peserta didik. Kegiatankegiatan yang dilaksanakan oleh takmir merupakan sebuah bentuk dakwah Islam .

Bentuk dakwah Islam merupakan sebuah bentuk dari komunikasi organisasi. Komunikasi sebagai proses penyampaian pesan oleh seseorang atau kelompok kepada orang lain untuk memberitahu, mengubah sikap, pendapat, atau sikap, baik secara lisan (langsung) ataupun tidak langsung (melalui media) (Effendy, 2003:10).

Jika dikaitkan dengan teori Lasswell (Effendy, 2003) penyampaian komunikasi dalam bentuk pesan dakwah Islam yang dilakukan oleh takmir masjid/ rohis dilakukan dalam kerangka memperdalam wawasan pengetahuan ilmu agama yang meliputi akidah, rukun Islam, rukun iman, ahlak terhadap sesama, yang tidak diperoleh dari mata pelajaran agama Islam di kelas. Bentuk dakwah ini merupakan sebuah proses oleh mentoring, khotib, maupun pembicara dalam menjelaskan halhal yang terkait dengan ilmu agama Islam. Saluran atau media yang digunakan dalam proses dakwah Islam ini melalui pengajian ahad pagi, khutbah Jumat, mentoring, belajar Islam akhir bulan, cermin hati, tadzabur alam dan lain sebagainya.

Masih terkait dengan teori Lasswell (Effendy, 2003), proses dakwah sebagai sebuah bentuk komunikasi diberikan sebagai sebuah umpan dengan harapan akan mendapat feedback atau umpan balik. Feedback yang diharapkan adalah berupa perubahan mind set, perubahan sikap dan komunikasi berantai. Komunikasi berantai yang dimaksud adalah komunikan berubah menjadi komunikator untuk menyampaikan pesan dakwah kepada orang lain melalui berbagai channel (media) seperti bulletin, facebook, twitter, majalah dinding, kuliah pagi, khutbah Jumat, mentoring, kesenian dan lain sebagainya.

\section{Komunikasi Takmir Masjid Nurul IImi dengan Pihak Luar}

Kegiatan takmir masjid/rohis tidak bisa berdiri sendiri dalam pelaksanaannya. Takmir masjid / rohis memerlukan kerjasama dengan pihak luar khususnya dalam hal sumberdaya manusia. Sumber daya manusia tersebut terkait dengan kompetensi pengetahuan yang dimiliki oleh pihak luar. Adapun komunikasi takmir masjid dengan pihak luar adalah sebagai berikut.

1. Komunikasi Takmir dengan ulama-ulama di Kota Pekalongan

Komunikasi yang dijalin dengan ulama-ulama di kota Pekalongan terkait dengan pembicara-pembicara dalam kegiatan takmir khususnya untuk mengisi pengajian- 
pengajian, istighosah, dan khotib khutbah Jumat. Beberapa tokoh ulama yang pernah mengisi pada kegiatan ini adalah ketua MUI jawa tengah Habib Lutfi bin Yahya, K.H Su'udi, KH Zainudin Ismail dari pesantren Krapyak, KH Sam'ani, Dosen STAIN Pekalongan, tokoh-tokoh Muhammadiyah Kota Pekalongan, guru-guru agama pada sekolah lain untuk mengisi khutbah Jumat maupun kuliah Ahad pagi.

2. Komunikasi dengan Perguruan tinggi

Kerjasama dengan perguruan tinggi terkait dengan kegiatan-kegiatan tahunan Takmir/rohis. Telah beberapa tahun ini SMAN 3 Pekalongan menjalin kerjasama dengan Sekolah Tinggi Agama Islam Negeri Pekalongan pada kegiatan Pesantren ramadhan. Pesantren ramadhan dilaksanakan selama satu minggu dengan mentormentor mahasiswa STAIN Pekalongan.

3. Jaringan dengan Alumni

Jaringan komunikasi dengan alumni takmir/rohis dibangun melalui kegiatan mentoring, pelatihan marawis, halal bi halal, dan kegiatan-kegiatan besar yang dilaksananakan oleh Takmir/rohis. Komunikasi yang dibangun ini untuk mempererat tali silaturahmi antara para alumni dengan peserta didik.

\section{Faktor Pendukung dan Penghambat Kegiatan Takmir Masjid}

\section{Faktor Pendukung}

Faktor internal adalah beberapa faktor pendukung keberhasilan pelaksanaan kegiatan rohis/takmir masjid. Faktor-faktor tersebut adalah kepemimpinan ketua Takmir masjid /rohis dan koordinasi serta konsulidasi internal dalam menjalankan program-program yang telah direncanakan, serta faktor bimbingan dari pembina takmir masjid. Kepemimpinan ketua takmir masjid Nurul Ilmi SMAN 3 Pekalongan sangat berpengaruh pada berhasil atau tidaknya pelaksanaan program. Pertama ketua takmir adalah peserta didik pilihan yang telah dipilih melalui 4 proses penyaringan, yaitu pengajuan bakal calon, penentuan calon, seleksi kompetensi, dan seleksi dari pembina takmir. Ketua Takmir Masjid Nurul Ilmi senantiasa mengambil tanggung jawab dalam setiap kegiatan yang dilaksanakannya. Tanggung jawab tersebut dilakukan dengan cara melakukan koordinasi dengan sesama pengurus. Jika terjadi konflik-konflik internal, ketua takmir masjid dapat meredakan konflik-konflik yang terjadi di internal organisasi. Konflikkonflik internal dapat diredakan dalam program "Cermin Hati" yaitu sebuah program untuk melakukan refleksi terhadap pribadi dan anggota pengurus.

Faktor internal yang lain adalah eratnya koordinasi dan konsolidasi antara sesama pengurus takmir masjid Nurul Ilmi. Konsulidasi ini dibuktikan dengan 
adanya monitoring yang dilakukan oleh ketua takmir melalui pembagian tugas pada koordinator seski dan sesksi-seksi di bawahnya. Faktor internal lain yang turut mendukung kegiatan takmir masjid adalah pembinaan oleh pembina takmir. Pembina Takmir Masjid Nurul Ilmi sesantiasa mendampingi kegiatan-kegiatan yang diprogram dan dilaksanakan oleh pengurus takmir. Pendampingan ini dilakukan dengan cara selalu hadir dalam setiap kegiatan takmir, mulai dari pemilihan pengurus baru, penerbitan, mentoring, dan lain sebagainya.

Dilihat dari faktor eksternal, faktor pendukung yang sangat berpengaruh pada keberhasilan program takmir masjid/rohis adalah kebijakan kepala sekolah serta sarana dan prasarana yang diberikan kepada takmir masjid/rohis. Meskipun organisasi takmir masjid Nurul Ilmi bukan menjadi oraganisasi wajib di SMAN 3 tetapi kebijakan kepala sekolah SMAN 3 yang mewajibakan seluruh peserta didik muslim mengikuti kegiatan-kegiatan yang dilakukan oleh Takmir masjid menjadi sebuah indikator keberhasilan penanaman nilai-nilai keagamaan dalam lingkungan sekolah dan pribadi peserta didik. Terlebih lagi keaktifan dalam segala bentuk kegiatan takmir masjid seperti salat Zuhur, salat jumat, kuliah Ahad pagi dan kegiatan-kegiatan yang melibatkan massa peserta didik ikut berpengaruh pada nilai mata pelajaran PAI menjadi salah satu usaha sekolah dalam membentuk sikap keagamaan peserta didiknya.

Dukungan kepala sekolah berupa dukungan moril kepada takmir masjid untuk menyusun program kegiatan secara bebas namun tetap masih dalam koridor-koridor yang diperbolehkan. Namun, untuk masalah dukungan dana kegiatan takmir/rohis tidak dianggarkan oleh anggaran sekolah untuk kegiatan-kegiatan yang besar. Tidak adanya dukungan dana dari sekolah tersebut justru merupakan faktor pendukung bagi takmir/rohis untuk mengembangkan diri menyusun proposal dan menjalin komunikasi kerjasama dengan pihak luar sekolah.

Faktor eksternal yang lain adalah sarana dan prasarana baik yang diusahakan oleh organisasi takmir/rohis maupun yang diberikan pihak sekolah untuk mensukseskan kegiatan takmir/rohis. Sarana dan prasarana yang diusahakan oleh Takmir Masjid Nurul Ilmi SMAN 3 berupa mukena, sarung, papan majalah dinding, dan buku-buku bacaan keagamaan. Fasilitas yang diberikan oleh sekolah berupa penyediaan masjid/mushola untuk kegiatan Takmir/rohis.

\section{Faktor penghambat Kegiatan Takmir Masjid Nurul Ilmi}

Faktor penghambat pembentukan sikap keagamaan dalam pelaksanaan kegiatan takmir/rohis dapat dilihat dari dua hal, yaitu faktor internal dan faktor eksternal. Faktor internal merupakan faktor dari tubuh organisasi takmir/rohis itu sendiri, 
sedangkan faktor ekternal berupa kebijakan dari sekolah. Berikut ini akan di deskripsikan faktor penghambat pada masing masing organisasi rohis.

Secara internal faktor Penghambat kegiatan Takmir Masjid Nurul Ilmi SMAN 3 Pekalongan adalah masalah pembagian tugas terkait banyaknya jumlah anggota pada seksi-seksi bidang yang menyebabkan saling mengandalkan sesama anggota atas tugas yang menjadi tanggung jawab masing-masing sesksi. Sebagai contoh adalah pada seksi pengelolaan website takmir masjid baik dalam facebook maupun twitter dalam beberapa bulan kurang dilakukan update atau pembaharuan materimateri dakwah.

Secara eksternal penghambat kegiatan takmir adalah masalah pendanaan dalam kegiatan berorganisasi. Tidak ada alokasi pendanaan untuk kegiatan takmir dari anggaran belanja sekolah, pendanaan kegiatan takmir diusahakan sendiri oleh pengurus dengan jalan menghimpun infak dari yang diambilkan dari peserta didik. Sedangkan untuk honor pembina takmir dianggarakan dari dana yang dihimpun oleh komite sekolah.

\section{ANALISIS}

\section{Analisis SWOT Terhadap Peran Takmir Dalam Usaha Membentuk Sikap Keagamaan Peserta Didik}

Analisa SWOT adalah alat yang digunakan untuk mengidentifikasi isu-isu internal dan eksternal yang mempengaruhi kemampuan takmir dalam upaya menjalankan programnya sehingga mampu mempengaruhi paradigma peserta didik yang pada akhirnya diharapkan mampu mempengaruhi peserta didik pada bidang kognitif, afeksi, psikomotorik dan behaviorismenya.

1. Analisis terhadap Strenght (Kekuatan)

Kekuatan-kekuatan yang dimiliki takmir masjid / rohis datang dari internal dan eksternal takmir. Faktor-faktor internal yang menjadi sumber kekuatan adalah Visi dan misi Takmir masjid Nurul Ilmi, yaitu mencetak generasi penerus yang mampu melanjutkan syiar Islam melalui kegiatan keagamaan. Sedangkan misi yang dikembangkan ada empat. Pertama, yaitu membentuk generasi penerus yang dapat mengamalkan agama Islam . Kedua, mewujudkan generasi penerus menjadi pemimpin yang berakhlak mulia. Ketiga, mengembangkan sikap dan kepribadian sesuai ajaran Islam. Keempat, mempersiapkan generasi penerus yang mampu menghadapi tantangan zaman. 
Melihat visi misi serta faktor internal maupun eksternal yang menjadi sumber kekuatan, takmir maupun rohis mempunyai harapan untuk eksis dalam melakukan gerakan dakwah. Sebab langkah awal dalam perumusan strategi (Strategy Formulation) adalah penetapan visi dan misi. Visi merupakan gambaran tentang masa depan (future) yang realistik dan ingin diwujudkan dalam kurun waktu tertentu. Visi yang telah disusun oleh takmir telah secara tepat diterjemahkan dalam guidelines yang lebih pragmatis dan kongkrit serta dapat dijadikan sebagai acuan dalam pengembangan strategi dan aktivitas dalam organisasi. Guideline tersebut ada dalam misi takmir/rohis. Dalam misi takmir/rohis berisi tentang pernyataan mengenai hal-hal yang harus dicapai oleh organisasi bagi pihak-pihak yang berkepentingan di masa yang akan datang.

Pernyataan misi takmir sebagai penjabaran visi memperlihatkan tugas utama yang harus dilakukan organisasi dalam mencapai tujuan organisasi. Pernyataan misi mengandung definisi yang jelas tentang pekerjaan atau tugas pokok yang diemban suatu organisasi dan yang diinginkan dalam kurun waktu tertentu. Pernyataan misi tersebut menunjukkan dengan jelas arti penting eksistensi organisasi, karena misi mewakili alasan dasar untuk berdirinya organisasi. Banyak organisasi gagal karena pernyataan misi yang dirumuskan hanya memperhatikan kepentingan dirinya sendiri dan mengabaikan kepentingan masyarakat pelanggan maupun pemakai dan stakeholder.

Analisis kekuatan berikutnya adalah dari faktor eksternal kebijakan kepala sekolah, motivasi guru pembina, serta sarana dan prasarana yang disediakan oleh sekolah untuk kegiatan takmir. Pada SMAN 3 Pekalongan kebijakan kepala sekolah, motivasi guru pembina serta sarana prasarana menjadi faktor eksternal yang turut mendukung eksistensi takmir. Kebijakan kepala sekolah berperan penting dalam berhasil tidaknya program kegiatan dakwah oleh takmir. Kebijakan tersebut di dukung oleh sarana dan prasarana sekolah seperti penyediaan masjid untuk tempat beraktifitas takmir. Kebijakan takmir yang menjadikan kegiatan keagamaan menjadi aktifitas wajib bagi seluruh peserta didik muslim menjadikan gerakan dakwah ini lebih masif dan berkembang.

Faktor lainnya adalah motivasi dan peran pembina takmir yang intensif. Pada takmir masjid Nurul Ilmi SMAN 3 terlihat bahwa motivasi guru pembina takmir dan peserta didik cukup tinggi sehingga mampu menyusun dan mengembangkan program-program serta metode dakwah yang efektif dan menarik sehingga peserta didik cukup antusias dalam merespon setiap kegiatan takmir. 
2. Analisis terhadap weaknesess (Kelemahan)

Secara umum kelemahan yang paling mendasar pada organisasi takmir/rohis adalah tidak adanya Angaran dasar dan Anggaran Rumah Tangga dalam menjalankan tugas sehari-hari. Layaknya sebuah organisasi yang sehat seharusnya takmir masjid / rohis memiliki panduan dalam menjalankan organisasinya seharihari. Pembagian tugas yang terkadang over laping dan saling tumpang tindih menjadikan organisasi rohis tidak sehat. Pembagian tugas dan fungsi pada masing masing pengurus dalam suatu kepengurusan serta bertanggung jawab dalam melaksanakannya merupakan kunci utama suatu organisasi takmir/rohis dapat survive dan menjadi oragnisasi yang diminati oleh peserta didik. Perlu diakui Rohis pada SMAN 3 Pekalongan bukanlah menjadi organisasi favorit yang menjadikan peserta didik mau bergabung dan mengembangkan dirinya bersama organisasi tersebut. Padahal jika dikelola dengan baik organisasi rohis dapat menjadikan anggotanya menjadi pribadi-pribadi yang matang dalam berorganisasi.

Matang berorganisasi artinya mampu mengembangkan diri, disegani, menjadi pilihan utama dan menjadi model bagi peserta didik yang lain. Sebagai akibat dari kematangan berorganisasi adalah setiap program-program yang dipromosikan akan mendapatkan perhatian tersendiri bagi pengikutnya. Jika telah mendapatkan perhatian tersendiri bagi pengikutnya maka dakwah yang dilakukan oleh Takmir masjid Nurul Ilmi sebagai bagian dari proses komunikasi akan mampu mengubah tingkah laku sikap keagamaan peserta didik. Hal itu sebagaimana teori komunikasi yang dikemukakan oleh Carl I Hovland (Mulyana, 2005:62) yaitu komunikasi merupakan proses penyampaian pesan yang bertujuan untuk merubah sikap seseorang.

3. Analisis tehadap opportunities (peluang)

Banyak peluang yang dimiliki oleh Takmir Masjid Nurul Ilmi andai kelemahankelemahan yang dimiliki oleh kedua organisasi tersebut mampu diminimalisir. Peluang tersebut berupa menjadikan organisasi takmir menjadi organisasi yang diminati oleh peserta didik dan tentu saja dapat menjadikan organisasi beserta anggotanya dan program-programnya menjadi sebuah model bagi peserta didik yang lain. Peluang-peluang tersebut dapat dicapai manakala kelemahan-kelemahan mulai dari AD/ART, kebijakan kepala sekolah, masalah rekrutiment dapat di upgrade atau ditingkatkan kompetensinya. Peningkatan kompetensi tersebut dapat dilakukan dengan berbagai cara salah satunya adalah dengan melakukan refleksi ke dalam tubuh organisasi oleh motivator-motivator yang dapat diambilkan dari guru pembina takmir/rohis yang memiliki kompetensi untuk memberikan motivasi. 


\section{Analisis terhadap treaths (ancaman-ancaman)}

Persoalan pokok yang menjadi ancaman atas eksistensi organisasi Rohis terdiri dari ancaman yang berasal dari internal dan eksternal organisasi. Ancaman-ancaman yang berasal dari internal organisasi berupa tidak adanya AD/ART, kebijakan sekolah, serta prasarana pendukung kegiatan rohis serta pendanaan.

Dalam tataran implementasi pergantian kepengurusan takmir masjid Nurul Ilmi sebenarnya telah menggunakan mekanisme-mekanisme yang telah biasa dilakukan secara turun temurun atau peneliti menyebutnya sebagai sebuah konvensi. Namun, konvensi ini tidaklah baku karena sewaktu-waktu dapat berubah dan tidak mengikat. Anggaran Dasar juga memuat tugas dan fungsi masing-masing struktur organisasi mulai dari ketua, wakil ketua, sekretaris, wakil sekretaris, bendahara, koordinator seksi bidang dan seksi bidang. Jika saja organisasi rohis mampu menyusun tugas dan fungsi pada masing-masing struktur maka dimungkinkan rohis akan menjadi organisasi yang solid.

Ancaman internal lainnya adalah pembina rohis yang tidak sesuai dengan yang diharapkan. Kompetensi pembina rohis belum memiliki motivasi untuk melakukan pendampingan terhadap organisasi yang dibinanya. Idealnya, kepala sekolah mampu menunjuk pembina-pembina rohis yang memiliki kompetensi dan kapabilitas dalam melakukan pendampingan, motivasi, dan evaluasi terhadap rohis. Tidak harus Guru Pendidikan Agama Islam tetapi cukuplah yang memiliki kriteria kapabilitas sebagai pendamping, motivasi, dan evaluasi.

Ancaman yang berasal dari eksternal adalah masalah kebijakan kepala sekolah. Kebijakan kepala sekolah yang tidak mewajibkan peserta didik muslim mengikuti setiap kegiatan rohis menyebabkan proses persemaian nilai-nilai keagamaan yang dilaksanakan pada kegiatan rohis menjadi tidak terjadi secara utuh. Artinya, hanya peserta didik yang butuh saja yang bersedia mengikuti kegiatan rohis seperti pengajian, salat Jumat, dan lain sebagainya. Idealnya kebijakan kepala sekolah menjadikan kegiatan rohis sebagai bagian dari penilaian kelulusan pada mata pelajaran agama Islam dapat meningkatkan gairah peserta didik untuk mengikuti kegiatan rohis. Dengan demikian, dakwah sebagai salah satu bentuk komunikasi diharapkan mampu mempengaruhi peserta didik pada bidang kognitif, afektif dan psikomotorik yang pada akhirnya mampu mempengaruhi tingkah laku keagamaan peserta didik.

Ancaman eksternal lainnya dalah sarana dan parasarana yang kurang memadai seperti letak masjid sulit dijangkau aksesnya. Ancaman eksternal ini sebenarnya dapat diatasi dengan cara membuka akses jalan menuju masjid sehingga mudah dijangkau, 
dan para jamaah atau peserta didik yang ingin ke masjid untuk melakukan ibadah tidak harus memutar dan melewati lorong yang sempit.

\section{PENUTUP}

Berdasarakan kajian data melalui wawancara, observasi dan telaah dokumen pada Rohis di SMAN 3 Pekalongan, penelitian ini menyimpulkan 4 kesimpulan sebagai berikut. Pertama, profil organisasi Kerohanian Islam yang ada di SMAN di Kota Pekalongan dapat berbentuk takmir masjid, maupun rohis. Organisasi ini memiliki peran dalam upaya dakwah Islam yang dikemas dalam kegiatankegiatannya seperti kuliah pagi, pengajian, istighosah dan lain sebagainya. Kedua, organisasi kerohanian Islam memiliki andil atau peran yang besar dalam menyemaikan dan membentuk watak dan sikap keagamaan peserta didik SMAN melalui kegiatan-kegiatan yang diselenggarakannya. Ketiga, faktor internal pendukung kegiatan rohis/takmir dalam perannya membentuk sikap keagamaan adalah visi misi takmir, kepemimpinan, kooordinasi dan konsulidasi antara pengurus takmir atau rohis. Secara eksternal faktor pendukung eksternal berupa kebijakan kepala sekolah. Adapun faktor penghambat internal yang menjadi penghambat rohis / takmir adalah tidak adanya mekanisme yang mengatur organisasi, dan pembagian tugas dan fungsi pada masing-masing struktur takmir/rohis. Secara eksternal penghambat kegiatan Rohis adalah kebijakan kepala sekolah yang tidak mewajibkan kegiatan rohis menjadi kegiatan wajib disekolah, kompetensi yang masih rendah salah satu pembina rohis dari organisasi yang di teliti, sarana dan prasarana untuk menunjang kegiatan takmir/rohis, serta masalah pendanaan dalam menjalankan organisasi. Keempat, takmir masjid Nurul Ilmi menjalin kerjasama dengan perguruan tinggi Islam, dan ulama-ulama di Kota Pekalongan.

\section{DAFTAR PUSTAKA}

Aliyah, Miftahul, 2008. Konflik Sosial Antara Pribumi dengan non Pribumi (Cina) di Pekalongan, Jawa Tengah, Skripsi, Yogyakarta, Universitas Islam Sunan Kalijaga.

Bogdan, Robert C, Blikhen, Knopp Sofi. 1982. Qualitation Research For Education An Introduction To Theory And Methods. Allya and Bacon. Boston House.

Daulay, Haidar Putra dan Pasa Nurqaya Pasa. 2012. Pendidikan Islam dalam Mencerdaskan Bangsa. Jakarta. Rineka Cipta.

Daradjat, Zakiyah. 1998. Kesehatan Mental. Jakarta. Haji Masagung. 
Effendy, 2003Onong Uchjana. Ilmu, teori dan filsafat komunikasi, Bandung, Citra Aditya Bakti.

Fuaduddin, TM 2007. Disertivikasi Pesantren dan Pendidikan Agama". "Jurnal Penelitian Pendidikan Agama dan Keagamaan Volume 5 Tahun 2007 Puslitbang Pendidikan Agama dan Keagamaan Badan Litbang dan Diklat Kementerian Agama RI.

Hemphill, JK dan Coons, AE. 1957. Development Of The Leader Behavior E Description questionnaire. In R.M. Stogdiel and A.E. Coons (eds) leader behavior: Its Description and Meansurement Columbus. Ohio : Bureau Of Bussines Research. Ohio State University.

Lucas, E Anton, 1989, Peristiwa Tiga Daerah:Revolusi dalam Revolusi), Bandung, Pustaka Grafiti Utama.

Mahmud. 2010. Pengantar Psikologi Pendidikan. Ed. Pupuh Fatturahman. Bandung. Pustaka Setia.

Muhaimin, 2012. Paradigma Pendidikan Islam: Upaya Mengefektifkan Pendidikan Agama Islam di Sekolah, Bandung: Remaja Rosdakarya.

Mulyana, Deddy. 2005. Ilmu Komunikasi Suatu Pengantar, Bandung, Remaja Rosdakarya.

Tholkhah, Imam. 2012. Sinopsis Hasil Penelitian E Pengembangan 2010-2011. Pendidikan Agama dan Keagamaan Puslitbang Pendidikan dan Keagamaan Badan Litbang dan Diklat Kementerian Agama RI.

Yusuf L.H, Syamsu. 2010. Psikologi Perkembangan Anak dan Remaja. Bandung. Rosdakarya.

Suromo, Yudi, 1995, “Kerusuhan di Pekalongan, dalam Majalah Gatra Vol IXX 2 Desember 1995. 


\section{PROSIDING}

Bidang Pendidikan Agama dan Keagamaan

Volume 2 No. 2 Tahun 2015 ISSN : 2354-5747

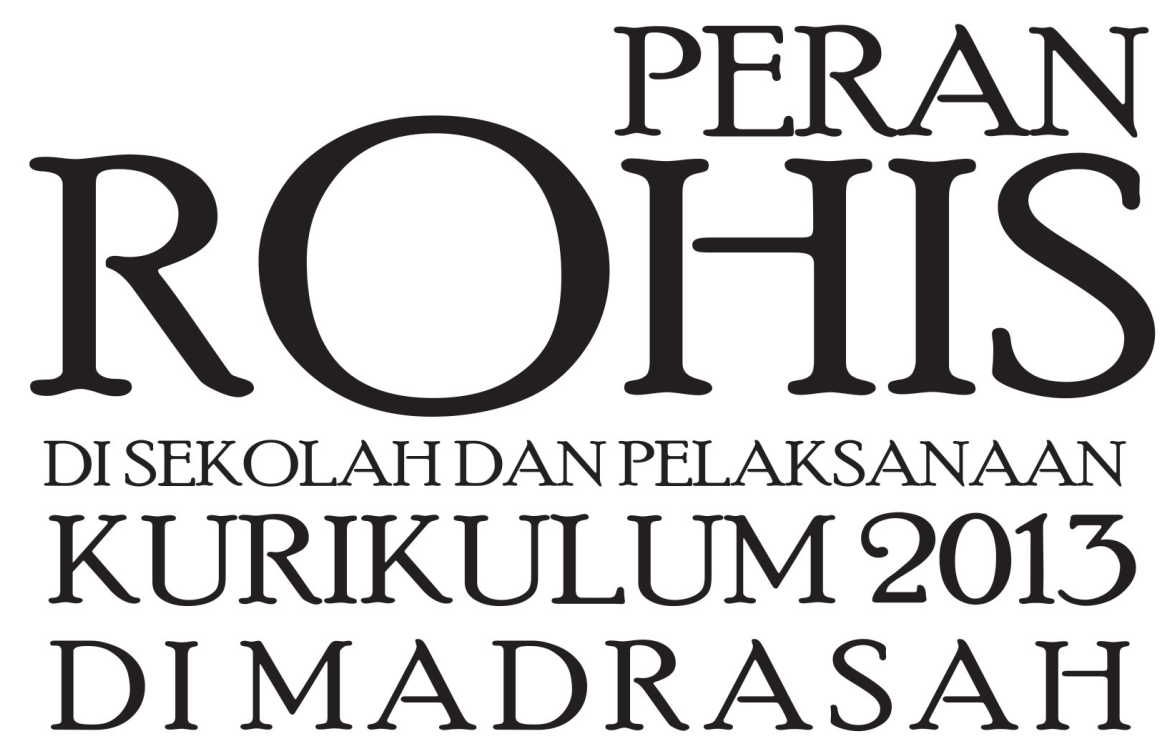

KEMENTERIAN AGAMA

Balai Penelitian dan Pengembangan Agama Semarang 2015 


\title{
Susunan Redaksi
}

Penanggung Jawab

Prof. (R) DR. H. Koeswinarno, M. Hum

(Kepala Balai Litbang Agama Semarang)

\author{
Dewan Penyunting \\ Mulyani Mudis Taruna \\ Yustiani \\ Mukhtaruddin \\ Umi Muzayanah \\ Wahab \\ Sulaiman \\ Joko Tri Haryanto \\ Umi Masfiah \\ Ahmad Sidik

\section{Layouter} \\ Musafak \\ Muhammad Purbaya
}


PERAN ROHIS DALAM PEMBENTUKAN PERILAKU KEAGAMAAN SISWA DI SEKOLAH (Studi Atas Peran Rohis At-Tarbiyah SMAN 1 Ungaran)

Umi Muzayanah 45

PERAN SOLIDARITAS KEROHANIAN ISLAM (SKI) SMAN 1 SALATIGA DALAM PEMBENTUKAN SIKAP DAN PERILAKU KEAGAMAAN PESERTA DIDIK

Wahab 71

PERAN ROHIS MAJLIS TAKLIM DALAM PEMBENTUKAN PERILAKU KEAGAMAAN PESERTA DIDIK SMAN 1 KENDAL

Yustiani S. 99

KESIAPAN MADRASAH TSANAWIYAH (MTs) DALAM PENERAPAN KURIKULUM 2013 (Studi Kesiapan Madrasah Tsanawiyah Negeri (MTsN) Kota Salatiga dalam Penerapan Kurikulum 2013)

Ahmad Muntakhib 119

KESIAPAN MADRASAH TSANAWIYAH NEGERI (MTsN) KOTA TEGAL DALAM PELAKSANAAN KURIKULUM 2013

Mukhtaruddin 143

KESIAPAN MADRASAH DALAM PELAKSANAAN KURIKULUM 2013

Mulyani Mudis Taruna 171

Lampiran-Lampiran

Lampiran 1 Notulensi 191

Lampiran 2 Surat Keputusan Panitia 201

Lampiran 3 Daftar Hadir Peserta 203

Lampiran 4 Jadwal Kegiatan 209 